\title{
Halobacillus alkaliphilus sp. nov., a halophilic bacterium isolated from a salt lake in Fuente de Piedra, southern Spain
}

\author{
Correspondence \\ Annarita Poli \\ apoli@icmib.na.cnr.it
}

\author{
Ida Romano, ${ }^{1}$ Ilaria Finore, ${ }^{1}$ Giancarlo Nicolaus, ${ }^{2}$ F. Javier Huertas, ${ }^{3}$ \\ Licia Lama, ${ }^{1}$ Barbara Nicolaus ${ }^{1}$ and Annarita Poli ${ }^{1}$
${ }^{1}$ Istituto di Chimica Biomolecolare, Comprensorio ex Olivetti, via Campi Flegrei 34, 80078 Pozzuoli, Napoli, Italy
${ }^{3} \mathrm{CSIC}$, Estacion Experimental del Zaidin, Department of Earth Sciences and Environmental Chemistry, Profesor Albareda 1, 18008 Granada, Spain \\ ${ }^{2}$ Istituto di Ricerche di Biologia Molecolare, IRBM, Pomezia, Italy
}

The genus Halobacillus was first described by Spring et al. (1996) to accommodate two novel species, Halobacillus litoralis and Halobacillus trueperi, and the transfer of Sporosarcina halophila (Claus et al., 1983) to Halobacillus as Halobacillus halophilus. At the time of writing, the genus comprises 13 species with validly published names, with the addition of Halobacillus salinus (Yoon et al., 2003), $H$. karajensis (Amoozegar et al., 2003), H. locisalis (Yoon et al., 2004), H. yeomjeoni (Yoon et al., 2005), H. dabanensis and $H$. aidingensis (Liu et al., 2005), $H$. profundi and $H$. kuroshimensis (Hua et al., 2007), H. campisalis (Yoon et al., 2007) and H. faecis (An et al., 2007).

\footnotetext{
The GenBank/EMBL/DDBJ accession number for the 16S rRNA gene sequence of strain $\mathrm{FP5}^{\mathrm{T}}$ is $\mathrm{AM} 295006$.

A scanning electron micrograph of cells of strain $\mathrm{FP}^{\top}$ and thin-layer chromatographs of total polar lipids of strain $\mathrm{FP5}^{\top}$ are available as supplementary material with the online version of this paper.
}

The genus Halobacillus can be differentiated clearly from other related genera based on the cell-wall peptidoglycan type based on L-Orn-D-Asp (Spring et al., 1996; Shida et al., 1997; Yoon et al., 2001), with the exception of that for $H$. campisalis, which is based on meso-diaminopimelic acid (Yoon et al., 2007). The aim of the present study was to determine the exact taxonomic status of a halophilic bacterial strain, $\mathrm{FP}^{\mathrm{T}}$, by using a polyphasic approach, including phenotypic properties, lipid analyses, phylogenetic analysis based on 16S rRNA gene sequences and levels of genotypic relatedness.

Strain $\mathrm{FP}^{\mathrm{T}}$ was isolated from samples collected during summer 2005 from Fuente de Piedra saline lake, Malaga province, southern Spain $\left(\begin{array}{lllll}37^{\circ} & 6^{\prime} & \mathrm{N} & 4^{\circ} & 44^{\prime} \mathrm{W}\end{array}\right)$. It was isolated from a saltern crystallizer pond by the dilutionplating technique. Strain $\mathrm{FP}^{\mathrm{T}}$ represented the predominant organism in the enrichment and was the only colonyforming organism at the highest dilutions. The enrichment medium (medium A) contained the following components 
(per litre distilled water): $10.0 \mathrm{~g}$ yeast extract (Oxoid), $3.0 \mathrm{~g}$ trisodium citrate (Applichem), $2.0 \mathrm{~g} \mathrm{KCl}$ (Applichem), $1.0 \mathrm{~g} \mathrm{MgSO}_{4} \cdot 7 \mathrm{H}_{2} \mathrm{O}$ (Carlo Erba), $100 \mathrm{~g}$

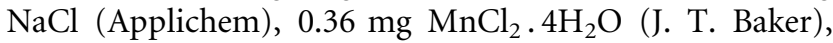
$0.05 \mathrm{~g} \mathrm{FeSO}_{4} .7 \mathrm{H}_{2} \mathrm{O}$ (Carlo Erba) and $3.0 \mathrm{~g} \mathrm{Na}_{2} \mathrm{CO}_{3}$ (Applichem). Solid media were prepared by the addition of $1.8 \%(\mathrm{w} / \mathrm{v})$ agar. The $\mathrm{pH}$ of medium A was 9.0.

Growth on single carbon sources was tested on liquid media containing (per litre distilled water) $100 \mathrm{~g} \mathrm{NaCl}$ (Applichem), $2.0 \mathrm{~g} \mathrm{KCl}, 1.0 \mathrm{~g} \quad \mathrm{MgSO}_{4} \cdot 7 \mathrm{H}_{2} \mathrm{O}, 16.4 \mathrm{~g}$ $\mathrm{MgCl}_{2} \cdot 6 \mathrm{H}_{2} \mathrm{O}$ (Riedel-de Haën), $0.2 \mathrm{~g} \mathrm{NaHCO}_{3}$ (J. T. Baker), $2.29 \mathrm{~g} \mathrm{CaCl}_{2} \cdot 2 \mathrm{H}_{2} \mathrm{O}$ (J. T. Baker), $152 \mathrm{mg} \mathrm{NH} \mathrm{Nl}_{4} \mathrm{Cl}$ (Applichem), $33 \mathrm{mg} \quad \mathrm{K}_{2} \mathrm{HPO}_{4}$ (Applichem), $0.26 \mathrm{mg}$ $\mathrm{FeCl}_{2} \cdot 4 \mathrm{H}_{2} \mathrm{O}$ (J. T. Baker) and $10.0 \mathrm{~g}$ of the tested compound.

Reference strains $H$. yeomjeoni DSM $17110^{\mathrm{T}}$, H. karajensis DSM $14948^{\mathrm{T}}, H$. trueperi DSM $10404^{\mathrm{T}}$ and H. halophilus DSM $2266^{\mathrm{T}}$, obtained from the Deutsche Sammlung von Mikroorganismen und Zellkulturen, Braunschweig, Germany (DSMZ), were grown in the media suggested by the culture collection [DSMZ medium no. 514 plus $3 \%$ (w/v) $\mathrm{NaCl}$ at $30{ }^{\circ} \mathrm{C}$ for $\mathrm{H}$. yeomjeoni; DSMZ medium no. 1 plus $10 \%(\mathrm{w} / \mathrm{v}) \mathrm{NaCl}$ at $38{ }^{\circ} \mathrm{C}$ for $H$. karajensis; DSMZ medium no. 755 at $30{ }^{\circ} \mathrm{C}$ for $\mathrm{H}$. trueperi; DSMZ medium no. 123 at $30{ }^{\circ} \mathrm{C}$ for $H$. halophilus].

Cell morphology was determined by phase-contrast microscopy (Zeiss) and by scanning electron microscopy. For scanning electron microscopy analysis, the samples were fixed for $24 \mathrm{~h}$ in $2.5 \%$ glutaraldehyde. Samples were dehydrated in ethanol, critical-point-dried, sputter-coated with gold (SEM BALTECMED 020) and observed by use of a Philips XL 20 environmental scanning electron microscope. Colony morphology was analysed on solid medium via a Leica $\mathrm{M} 8$ stereomicroscope. Tolerance of $\mathrm{NaCl}$ and $\mathrm{MgSO}_{4}$ and growth at various temperatures and $\mathrm{pH}$ were tested in medium A. Growth tests were performed at the optimal growth temperature $\left(37^{\circ} \mathrm{C}\right)$ for 2 days. The $\mathrm{pH}$ range for growth was determined by adjusting the $\mathrm{pH}$ to $4.0-11.0$ with $\mathrm{HCl}$ and $\mathrm{NaOH}$. The temperature range for growth was determined by incubation in liquid medium at temperatures between 20 and $60{ }^{\circ} \mathrm{C}$. Sensitivity of the strain to antibiotics was tested by using medium A with agar $(1.8 \%, \mathrm{w} / \mathrm{v})$ and Sensi discs (6 mm; Oxoid) (Romano et al., 1993). Motility was assessed by using test tubes containing medium A with agar $(0.5 \%, \mathrm{w} / \mathrm{v})$. Phenotypic tests were performed according to the proposed minimal standards for the description of novel taxa within the order Halobacteriales (Oren et al., 1997). Gelatin hydrolysis was determined as described by Oren et al. (2002). Hydrolysis of casein and activities of oxidase, tyrosinase, aminopeptidase (Bactident-Merck) and catalase were tested in medium A as described by Oren et al. (1997). For tests of nitrate reduction, medium A plus $0.1 \%(\mathrm{w} / \mathrm{v}) \mathrm{KNO}_{3}$ was employed. Hydrolysis of hippurate was assessed in medium A plus hippurate $(1 \%, \mathrm{w} / \mathrm{v})$ (Poli et al., 2006). To test for the presence of indole, strain $\mathrm{FP}^{\mathrm{T}}{ }^{\mathrm{T}}$ was grown at $\mathrm{pH} 8.0$ in medium A. Gram-staining was performed according to Dussault (1955). The KOH test was performed according to Halebian et al. (1981). Tests for the hydrolysis of $N^{\prime}$ benzoyl-arginine- $p$-nitroanilide stereoisomers were performed according to Oren \& Galinski (1994). Cell mass for quinone and lipid analysis was obtained from cultures of test strains grown under their optimal growth conditions for $24 \mathrm{~h}$. Lipid analysis, lipid hydrolysis and identification of core lipids were performed as reported by Nicolaus et al. (2001). For quantitative determination of fatty acid composition, fatty acid methyl ester mixtures were prepared following the instructions of the Microbial Identification System (MIDI). Quinones were analysed by LC/MS on a reversed-phase column and by electron ionization/MS and ${ }^{1} \mathrm{H}$ NMR spectra. Phospholipids and glycolipids were separated by TLC on silica gel plates $\left(10 \times 10 \mathrm{~cm}, 10 \times 25 \mathrm{~cm}, 0.25 \mathrm{~mm}, \mathrm{~F}_{254}\right.$; Merck) and were analysed according to Nicolaus et al. (2001). Peptidoglycan analyses were performed by using the methods of Schleifer \& Kandler (1972), Schleifer (1985), MacKenzie (1987) and Groth et al. (1996).

The DNA G + C content was determined by the method of Tamaoka \& Komagata (1984). DNA was isolated by using a French pressure cell (Thermo Spectronic) and was purified by chromatography on hydroxyapatite as described by Cashion et al. (1977). The 16S rRNA gene sequence was determined by direct sequencing of the PCR products. Genomic DNA extraction, amplification of the 16S rRNA gene and purification of the PCR products were carried out as described by Reed et al. (2006) with primers 5' -ATGTAAGCTCCTGGGGTTCAC- ${ }^{\prime}$ and $5^{\prime}$-AGAAAGGAGGTGATCCAGCC- $3^{\prime}$. Purified PCR products were sequenced at the DSMZ by using the ABI PRISM Dye Terminator cycle sequencing ready reaction kit (Applied Biosystems) according to the manufacturer's protocol. Sequence reaction products were electrophoresed by using an Applied Biosystems 373A DNA sequencer. Sequencing of the $16 \mathrm{~S}$ rRNA gene and phylogenetic analysis were performed as described by Romano et al. (2007). DNADNA hybridization experiments were performed as described by De Ley et al. (1970) with the modifications given by Huß et al. (1983) by using a model Cary 100 Bio UV/Vis spectrophotometer equipped with a Peltier-thermostatted $6 \times 6$ multicell changer and a temperature controller with in-situ temperature probe (Varian). Hybridizations were carried out between strain $\mathrm{FP}^{\mathrm{T}}$ and the type strains of related species ( $H$. yeomjeoni DSM $17110^{\mathrm{T}}, H$. karajensis DSM $14948^{\mathrm{T}}$, H. trueperi DSM $10404^{\mathrm{T}}$ and H. halophilus DSM $2266^{\mathrm{T}}$ ).

Cells of strain $\mathrm{FP}^{\mathrm{T}}$ were Gram-positive, spore-forming cocci, occurring singly or in bunches, and measured $1.57 \mu \mathrm{m}$ in diameter (see Supplementary Fig. S1 in IJSEM Online). The coccoid morphology of the cells remained the same in all phases of growth. After incubation for 2 days, colonies of strain $\mathrm{FP}^{\mathrm{T}}$ were about 1-2 $\mathrm{mm}$ in diameter, circular, smooth and pale orange. Strain $\mathrm{FP}^{\mathrm{T}}$ required $\mathrm{Na}^{+}$and $\mathrm{Mg}^{2+}$ for growth, but was 
also able to grow using $\mathrm{K}^{+}$instead of $\mathrm{Na}^{+}$. Strain $\mathrm{FP}^{\mathrm{T}}$ grew in media containing $0.5-20 \%(\mathrm{w} / \mathrm{v}) \mathrm{NaCl}$; optimal growth occurred with $10 \%(\mathrm{w} / \mathrm{v}) \mathrm{NaCl}$. Strain $\mathrm{FP}^{\mathrm{T}}$ grew at temperatures of $25-45{ }^{\circ} \mathrm{C}$, with optimum growth at $37^{\circ} \mathrm{C}$. The optimum $\mathrm{pH}$ for growth was 9.0. Growth was observed up to $\mathrm{pH} \mathrm{10}$, but no growth occurred below $\mathrm{pH}$ 6.0. This optimum alkaline $\mathrm{pH}$ for growth was not found for other Halobacillus species (Spring et al., 1996; Claus et al., 1983; Yoon et al., 2003, 2004, 2005; Amoozegar et al., 2003; Liu et al., 2005).

Strain $\mathrm{FP} 5^{\mathrm{T}}$ was aerobic and catalase- and oxidase-positive. Acid was produced from glucose, trehalose, maltose, ribose, sucrose, raffinose, fructose and mannose, but not from galactose, cellobiose or xylose. Tyrosine was hydrolysed, but starch, casein, hippurate, gelatin and urease were not. The strain was negative for nitrate reduction and phenylalanine deaminase. Strain $\mathrm{FP} 5^{\mathrm{T}}$ was sensitive to $(\mu \mathrm{g}$ per disc) bacitracin (10), tetracycline (30), novobiocin (30), erythromycin (5), ampicillin (25), chloramphenicol
(10), fusidic acid (10), penicillin (10 U), lincomycin (10) and vancomycin (30), but resistant to ( $\mu \mathrm{g}$ per disc) streptomycin (25), nystatin (100), kanamycin (30) and neomycin (30). Detailed results of morphological analyses and biochemical tests for strain $\mathrm{FP}^{\mathrm{T}}$ are given in the species description. Differential characteristics between strain $\mathrm{FP}^{\mathrm{T}}$ and recognized species of the genus Halobacillus are given in Table 1. Of particular note was that only strain $\mathrm{FP}^{\mathrm{T}}$ was positive for tyrosine hydrolysis and that no growth was observed at $<5 \%(\mathrm{w} / \mathrm{v}) \mathrm{NaCl}$ for this strain. This appears to be the first report of an alkaliphilic member of the genus Halobacillus. Cell-wall analysis revealed that the peptidoglycan type of strain $\mathrm{FP}^{\mathrm{T}}$ was A4 $\beta$ based on L-Orn-D-Asp. The predominant menaquinone was MK-7, as reported for H. halophilus, the type species of the genus. The major fatty acids were anteiso- $\mathrm{C}_{15: 0}(40.4 \%)$, anteiso- $\mathrm{C}_{17: 0}(31.0 \%)$, iso- $\mathrm{C}_{15: 0}$ $(9.6 \%)$ and iso- $\mathrm{C}_{16: 0}(8.3 \%)$. The polar lipid profile of strain $\mathrm{FP}^{\mathrm{T}}$ was quite similar to the complex lipid patterns reported for recognized Halobacillus species, with the

Table 1. Differential characteristics between strain $\mathrm{FP}^{\top}$ and recognized Halobacillus species

Taxa: 1, strain $\mathrm{FP}^{\mathrm{T}}$; 2, H. halophilus (data from the present study and from Claus et al., 1983; Spring et al., 1996); 3, H. trueperi (Spring et al., 1996); 4, H. litoralis (Spring et al., 1996); 5, H. salinus (Yoon et al., 2003); 6, H. karajensis (Amoozegar et al., 2003); 7, H. locisalis (Yoon et al., 2004); 8, H. dabanensis (Liu et al., 2005); 9, H. aidingensis (Liu et al., 2005); 10, H. yeomjeoni (Yoon et al., 2005); 11, H. profundi (Hua et al., 2007); 12, H. kuroshimensis (Hua et al., 2007). +, Positive; -, negative; w, weakly positive; v, variable; ND, no data available.

\begin{tabular}{|c|c|c|c|c|c|c|c|c|c|c|c|c|}
\hline Characteristic & 1 & 2 & 3 & 4 & 5 & 6 & 7 & 8 & 9 & 10 & 11 & 12 \\
\hline Cell morphology & Coccoid & Coccoid & Rods & Rods & Rods & Rods & Rods & Rods & Rods & $\begin{array}{c}\text { Rods/long } \\
\text { filamentous rods }\end{array}$ & Rods & Rods \\
\hline Spore shape ${ }^{\star}$ & s & s & E or $S$ & E or $S$ & E & $\mathrm{E}$ or $\mathrm{S}$ & E & E & $\mathrm{E}$ & E & E or $S$ & E or $S$ \\
\hline Colony colour $\dagger$ & POW & $\mathrm{O}$ & $\mathrm{O}$ & $\mathrm{O}$ & POW & CW & LOW & $\mathrm{O}$ & $\mathrm{O}$ & LY & PY & YO \\
\hline Motility & - & + & + & + & + & - & + & + & + & + & - & - \\
\hline $\mathrm{pH}$ optimum & 9.0 & 7.2 & 7.5 & 7.5 & 7.0 & $7.5-8.5$ & $7-8$ & 7.5 & 7.5 & $7-8$ & $7.5-8.0$ & $7.5-8.0$ \\
\hline \multicolumn{13}{|c|}{$\mathrm{NaCl}$ concentration for growth $(\% \mathrm{w} / \mathrm{v})$} \\
\hline Range & 5-25 & $2-20$ & $0.5-30$ & $0.5-25$ & $0-23$ & $1-24$ & $>0.5-24$ & $0.5-25$ & $0.5-20$ & $0.5-21$ & $0.5-30.0$ & $0.5-25.0$ \\
\hline Optimum & 10 & 10 & 10 & 10 & $2-10$ & 10 & 10 & 10 & 10 & $3-5$ & 10 & 6 \\
\hline \multicolumn{13}{|l|}{ Hydrolysis of: } \\
\hline \multicolumn{13}{|l|}{ Acid production from: } \\
\hline D-Fructose & + & - & + & + & + & + & + & + & + & - & + & + \\
\hline D-Galactose & - & - & + & - & $\mathrm{w}$ & - & - & - & - & - & - & - \\
\hline Maltose & + & - & + & + & + & + & - & + & + & + & + & + \\
\hline Sucrose & + & - & + & + & + & - & + & + & + & + & + & $\mathrm{W}$ \\
\hline D-Xylose & + & - & - & + & - & - & - & + & - & - & + & - \\
\hline D-Glucose & + & - & + & + & + & + & + & + & + & + & + & + \\
\hline Trehalose & + & - & + & + & + & $\mathrm{ND}$ & + & + & + & + & + & - \\
\hline DNA G $+C$ content $(\mathrm{mol} \%)$ & 43.5 & $40.1-40.9$ & 43 & 42 & 45 & 41.3 & 44 & 41.4 & 42.2 & 42.9 & 43.3 & 42.1 \\
\hline
\end{tabular}

${ }^{\star}$ E, Ellipsoidal; s, spherical.

$\dagger \mathrm{CW}$, Cream or white; LOW, light orange-yellow; LY, light yellow; o, orange; POw, pale orange-yellow; PY, pale yellow; Yo, yellow-orange. 
presence of two phospholipids, phosphatidylglycerol, diphosphatidylglycerol and an unidentified glycolipid as major lipids. By using two-dimensional TLC, eluted with chloroform/methanol/water ( $65: 25: 4$ by volume) for the first dimension and with chloroform/methanol/acetic acid/ water $(85: 15: 12: 4$ by volume) for the second dimension, the lipid profile of strain $\mathrm{FP}^{\mathrm{T}}$ revealed the presence of two minor phospholipids and one minor glycolipid (Supplementary Fig. S2).

The complete 16S rRNA gene sequence of strain $\mathrm{FP}^{\mathrm{T}}$ determined in this study comprised $1484 \mathrm{nt}$. Comparative $16 \mathrm{~S}$ rRNA gene sequence analyses showed that strain $\mathrm{FP} 5^{\mathrm{T}}$ was phylogenetically most closely affiliated to members of the genus Halobacillus (Fig. 1). In the phylogenetic tree based on the neighbour-joining algorithm, strain $\mathrm{FP}^{\mathrm{T}}$ fell within the radiation of the cluster comprising Halobacillus species (Fig. 1). The 16S rRNA gene sequence of strain $\mathrm{FP}^{\mathrm{T}}$ showed similarity levels of $97.0-99.0 \%$ with respect to sequences of the type strains of recognized Halobacillus species (Fig. 1).

The above results indicated that strain $\mathrm{FP}^{\mathrm{T}}$ was a member of the genus Halobacillus. However, it could be distinguished from recognized species of the genus Halobacillus on the basis of several phenotypic characteristics (Table 1).

The DNA G+C content of strain $\mathrm{FP}^{\mathrm{T}}$ was $43 \mathrm{~mol} \%$. Mean levels of DNA-DNA relatedness between strain $\mathrm{FP} 5^{\mathrm{T}}$ and the type strains of recognized Halobacillus species were in the range $4.5-35 \%$ ( $H$. trueperi, $4.5 \% ; H$. salinus, $10.5 \%$; H. karajensis, $18.2 \%$; H. yeomjeoni, $22.5 \%$; $H$. dabanensis, $30.3 \%$; H. halophilus, $35.0 \%$ ). Therefore, on the basis of the data presented, strain $\mathrm{FP}^{\mathrm{T}}$ should be placed in the genus Halobacillus as a member of a novel species, for which the name Halobacillus alkaliphilus sp. nov. is proposed.

\section{Description of Halobacillus alkaliphilus sp. nov.}

Halobacillus alkaliphilus (al.ka.li.phi'lus. N.L. n. alkali alkali; Gr. adj. philos loving; N.L. masc. adj. alkaliphilus loving alkaline conditions).

Cells are Gram-positive, spore-forming cocci $(1.57 \mu \mathrm{m}$ in diameter). Colonies on agar medium are circular (1-2 mm in diameter), smooth and pale orange. Growth occurs at $\mathrm{NaCl}$ concentrations of $0.5-20 \%(\mathrm{w} / \mathrm{v})$, with optimal growth at $10 \%(\mathrm{w} / \mathrm{v})$, at temperatures of $25-45{ }^{\circ} \mathrm{C}$, with optimum growth at $37^{\circ} \mathrm{C}$, and at $\mathrm{pH} 6.0-10.0$, with optimum growth at $\mathrm{pH} 9.0$. Aerobic. Catalase- and oxidase-positive. Acid is produced from xylose, glucose, trehalose, maltose, ribose, sucrose, raffinose, fructose and mannose, but not from galactose or cellobiose. Hydrolyses tyrosine, but not starch, casein, hippurate, gelatin or urease. Negative for nitrate reduction and phenylalanine deaminase. The peptidoglycan type is A4 $\beta$ based on L-OrnD-Asp. The major menaquinone is MK-7. The major fatty acids are anteiso- $\mathrm{C}_{15: 0}(40.4 \%)$, anteiso- $\mathrm{C}_{17: 0}$ $(31.0 \%)$, iso- $\mathrm{C}_{15: 0}(9.6 \%)$ and iso- $\mathrm{C}_{16: 0}(8.3 \%)$. Major lipids are two phospholipids (phosphatidylglycerol and diphosphatidylglycerol) and one unidentified glycolipid. The DNA G + C content of the type strain is $43.5 \mathrm{~mol} \%$ $\left(T_{\mathrm{m}}\right)$.

The type strain, $\mathrm{FP}^{\mathrm{T}}\left(=\mathrm{DSM} 18525^{\mathrm{T}}=\right.$ ATCC BAA$1361^{\mathrm{T}}$ ), was isolated from Fuente de Piedra salt lake, southern Spain.

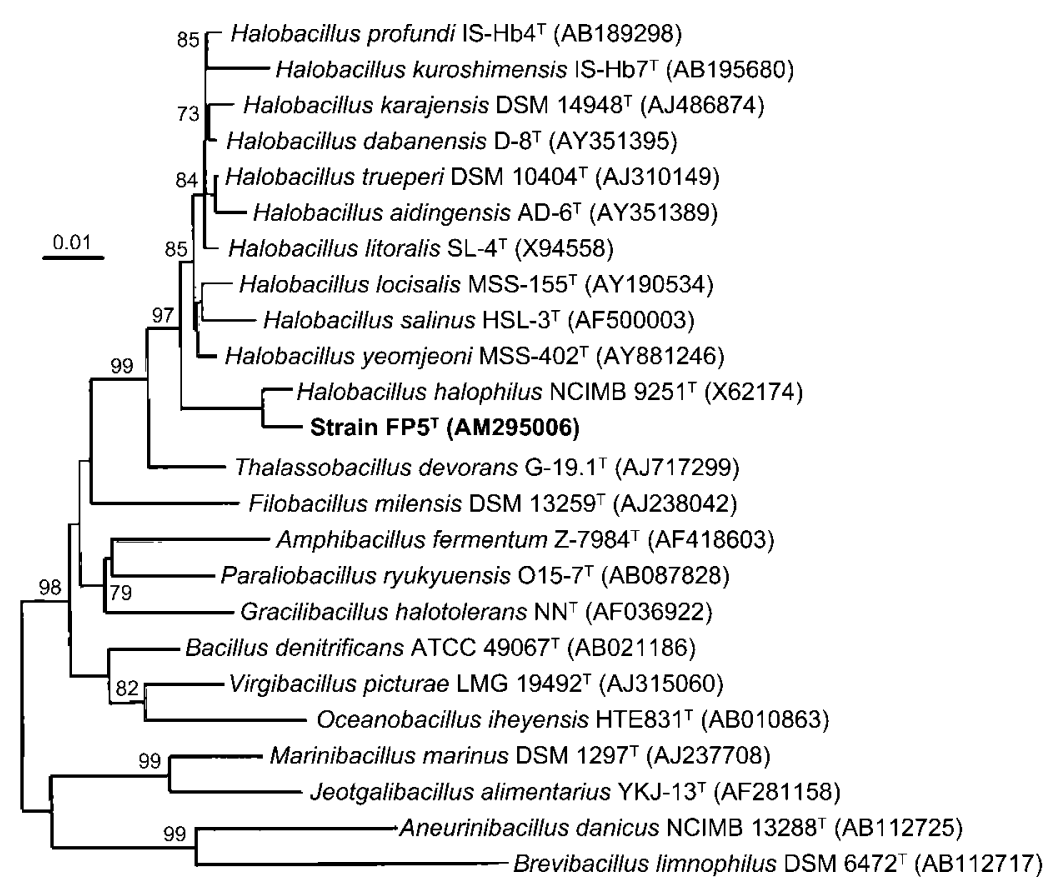

Fig. 1. Neighbour-joining tree, based on $16 \mathrm{~S}$ rRNA gene sequence data, showing the phylogenetic positions of strain $\mathrm{FP}^{\top}{ }^{\top}$, recognized Halobacillus species and some other related taxa. Bootstrap values (\%) are based on 1000 replicates and are shown at each node. Bar, 0.01 expected changes per site. 


\section{Acknowledgements}

This work was partially supported by Regione Campania. We thank Valeria Calandrelli and Eduardo Pagnotta for technical assistance, Vincenzo Mirra and Dominique Melck for NMR imaging and Raffaele Turco for artwork. We are grateful to $\mathrm{Dr}$ Salvatore Pelliccione and Dr Manuel Rendon (Director-Curator of Fuente de Piedra Natural Reserve) for their assistance during sampling and to Dr J. P. Euzéby for help with etymology.

\section{References}

Amoozegar, M. A., Malekzadeh, F., Malik, K. A., Schumann, P. \& Spröer, C. (2003). Halobacillus karajensis sp. nov., a novel moderate halophile. Int J Syst Evol Microbiol 53, 1059-1063.

An, S.-Y., Kanoh, K., Kasai, H., Goto, K. \& Yokota, A. (2007). Halobacillus faecis sp. nov., a spore-forming bacterium isolated from a mangrove area on Ishigaki Island, Japan. Int J Syst Evol Microbiol 57, 2476-2479.

Cashion, P., Holder-Franklin, M. A., McCully, J. \& Franklin, M. (1977). A rapid method for the base ratio determination of bacterial DNA. Anal Biochem 81, 461-466.

Claus, D., Fahmy, F., Rolf, H. J. \& Tosunoglu, N. (1983). Sporosarcina halophila sp. nov., an obligate, slightly halophilic bacterium from salt marsh soils. Syst Appl Microbiol 4, 496-506.

De Ley, J., Cattoir, H. \& Reynaerts, A. (1970). The quantitative measurement of DNA hybridization from renaturation rates. Eur $J$ Biochem 12, 133-142.

Dussault, H. P. (1955). An improved technique for staining red halophilic bacteria. J Bacteriol 70, 484-485.

Groth, I., Schumann, P., Weiss, N., Martin, K. \& Rainey, F. A. (1996). Agrococcus jenensis gen. nov., sp. nov., a new genus of actinomycetes with diaminobutyric acid in the cell wall. Int J Syst Bacteriol 46, 234-239.

Halebian, S., Harris, B., Finegold, S. M. \& Rolfe, R. (1981). Rapid method that aids in distinguishing Gram-positive from Gramnegative anaerobic bacteria. J Clin Microbiol 13, 444-448.

Hua, N.-P., Kanekiyo, A., Fujikura, K., Yasuda, H. \& Naganuma, T. (2007). Halobacillus profundi sp. nov. and Halobacillus kuroshimensis sp. nov., moderately halophilic bacteria isolated from a deep-sea methane cold seep. Int J Syst Evol Microbiol 57, 1243-1249.

Huß, V. A. R., Festl, H. \& Schleifer, K. H. (1983). Studies on the spectrophotometric determination of DNA hybridization from renaturation rates. Syst Appl Microbiol 4, 184-192.

Liu, W. Y., Zeng, J., Wang, L., Dou, Y. T. \& Yang, S. S. (2005). Halobacillus dabanensis sp. nov. and Halobacillus aidingensis sp. nov., isolated from salt lakes in Xinjiang, China. Int J Syst Evol Microbiol 55, 1991-1996.

MacKenzie, S. L. (1987). Gas chromatographic analysis of amino acids as the $N$-heptafluorobutyryl isobutyl esters. I Assoc Off Anal Chem 70, 151-160.

Nicolaus, B., Manca, M. C., Lama, L., Esposito, E. \& Gambacorta, A. (2001). Lipid modulation by environmental stresses in two models of extremophiles isolated from Antarctica. Polar Biol 24, 1-8.

Oren, A. \& Galinski, E. A. (1994). Hydrolysis of $N^{\prime}$-benzoyl-argininep-nitroanilide stereoisomers as a phenotypic test: a study of Grampositive halotolerant bacteria. Syst Appl Microbiol 17, 7-10.
Oren, A., Ventosa, A. \& Grant, W. D. (1997). Proposal of minimal standards for the description of new taxa in the order Halobacteriales. Int J Syst Bacteriol 47, 233-238.

Oren, A., Elevi, R., Watanabe, S., Ihara, K. \& Corcelli, A. (2002). Halomicrobium mukohataei gen. nov., comb. nov., and emended description of Halomicrobium mukohataei. Int J Syst Evol Microbiol 52, 1831-1835.

Poli, A., Esposito, E., Lama, L., Orlando, P., Nicolaus, G., de Apollonia, F., Gambacorta, A. \& Nicolaus, B. (2006). Anoxybacillus amylolyticus sp. nov., a thermophilic amylase producing bacterium isolated from Mount Rittmann (Antarctica). Syst Appl Microbiol 29, 300-307.

Reed, A. J., Lutz, R. A. \& Vetriani, C. (2006). Vertical distribution and diversity of bacteria and archaea in sulphide and methane-rich cold seep sediments located at the base of the Florid Escarpment. Extremophiles 10, 199-211.

Romano, I., Manca, M. C., Lama, L., Nicolaus, B. \& Gambacorta, A. (1993). A method for antibiotic assay on Sulfolobales. Biotechnol Tech 7, 439-440.

Romano, I., Poli, A., Finore, I., Huertas, F. J., Gambacorta, A., Pelliccione, S., Nicolaus, G., Lama, L. \& Nicolaus, B. (2007). Haloterrigena hispanica sp. nov., an extremely halophilic archaeon from Fuente de Piedra, southern Spain. Int J Syst Evol Microbiol 57, 1499-1503.

Schleifer, K. H. (1985). Analysis of the chemical composition and primary structure of murein. Methods Microbiol 18, 123-156.

Schleifer, K. H. \& Kandler, O. (1972). Peptidoglycan types of bacterial cell walls and their taxonomic implications. Bacteriol Rev 36, 407-477.

Shida, O., Takagi, H., Kadowaki, K., Nakamura, L. K. \& Komagata, K. (1997). Transfer of Bacillus alginolyticus, Bacillus chondroitinus, Bacillus curdlanolyticus, Bacillus glucanolyticus, Bacillus kobensis, and Bacillus thiaminolyticus to the genus Paenibacillus and emended description of the genus Paenibacillus. Int J Syst Bacteriol 47, 289-298.

Spring, S., Ludwig, W., Marquez, M. C., Ventosa, A. \& Schleifer, K.-H. (1996). Halobacillus gen. nov., with descriptions of Halobacillus litoralis sp. nov. and Halobacillus trueperi sp. nov., and transfer of Sporosarcina halophila to Halobacillus halophilus comb. nov. Int J Syst Bacteriol 46, 492-496.

Tamaoka, J. \& Komagata, K. (1984). Determination of DNA base composition by reversed-phase high-performance liquid chromatography. FEMS Microbiol Lett 25, 125-128.

Yoon, J.-H., Weiss, N., Lee, K.-C., Lee, I.-S., Kang, K. H. \& Park, Y.-H. (2001). Jeotgalibacillus alimentarius gen. nov., sp. nov., a novel bacterium isolated from jeotgal with L-lysine in the cell wall, and reclassification of Bacillus marinus Rüger 1983 as Marinibacillus marinus gen. nov., comb. nov. Int J Syst Evol Microbiol 51, 2087-2093.

Yoon, J.-H., Kang, K. H. \& Park, Y.-H. (2003). Halobacillus salinus sp. nov., isolated from a salt lake on the coast of the East Sea in Korea. Int J Syst Evol Microbiol 53, 687-693.

Yoon, J.-H., Kang, K. H., Oh, T.-K. \& Park, Y.-H. (2004). Halobacillus locisalis sp. nov., a halophilic bacterium isolated from a marine solar saltern of the Yellow Sea in Korea. Extremophiles 8, 23-28.

Yoon, J.-H., Kang, S.-J., Lee, C.-H., Oh, H. W. \& Oh, T.-K. (2005). Halobacillus yeomjeoni sp. nov., isolated from a marine solar saltern in Korea. Int J Syst Evol Microbiol 55, 2413-2417.

Yoon, J.-H., Kang, S.-J., Jung, Y.-T. \& Oh, T.-K. (2007). Halobacillus campisalis sp. nov., containing meso-diaminopimelic acid in the cellwall peptidoglycan, and emended description of the genus Halobacillus. Int J Syst Evol Microbiol 57, 2021-2025. 